Розман Ірина Іллівна кандидат педагогічних наук, доцент, доцент кафедри англійської мови, літератури з методиками навчання, Мукачівський державний університет, вул. Ужгородска, 26, м. Мукачево, 89600, тел.: (03131) 240-20, https://orcid.org/0000-0002-4951-0074

\title{
АКАДЕМІЧНА ДОБРОЧЕСНІСТЬ ЯК ВАЖЛИВА СКЛАДОВА ЯКІСНОÏ ОСВІТИ
}

Анотація. У статтірозглядаються питанняпро значення академічної доброчесності у освітньому процесі для підготовки конкурентоспроможного фахівця, який здатний самостійно проводити дослідження, чесно і $з$ повагою до однодумців посилатися на їх здобутки. Наголошено на тому, що моральноетична норма служить якісним орієнтиром та еталоном для того, щоб усвідомлювати власну відповідальність за порушення етичних норм у освіті.У статті зауважено на тому, що, насамперед, академічна доброчесність - це морально-етична норма, яку повинні дотримуватись всі представники освітнього i наукового середовища. За визначенням дефініції поняття вона починається 3 поведінки учнів, батьків, адміністрації школи. Особливої актуальності академічна доброчесність набуває саме тому, що така моральноетична норма служить якісним орієнтиром та еталоном, на який прийнято рівнятись. Запропоновано прості, але цілком дієві норми дотримуватись чесних навчальних відносин під час здобуття вищої освіти. Рекомендовано ознайомитись 3 елементами дослідження дотримання академічної доброчесності у закладах освіти Європи. Наголошено на думці перспективних фахівців щодо розвинення емоційного інтелекту. Він у сучасному світі виходить на перший план: лише взаємодія розвиненого інтелекту та емоційночутливого стану допоможе студентам досягнутирезультативності в майбутньому виборі професії. Такий симбіозсформує всебічний розвиток особистості, зміцнить знання і навички та сприятиме серйозному іміджу. Зауважено, що кожен заклад вищої освіти, кожна кафедра керується встановленими відсотками унікальності тексту. Для перевірки робіт на плагіат існує підписана угода ряду університетів 3 компанією Unicheck. Принцип роботи платформи полягає у використанні системою сучасних технологій та інтуїтивного дизайну 3 метою підвищення якості й оригінальності текстів. Наголошено, що проблему дотримання академічної доброчесності неможливо вирішити за рік-два: вона належить до морально-етичних норм: хоча два рази на тиждень необхідно студентам наголошувати на повазі один до одного, на необхідність більше часу відводити на виконання письмових робіт. 
Ключові слова: академічна доброчесність, моральність, етика, повага, довіра, дослідження, результат.

Rozman Irina Illivna Candidate of Pedagogical Sciences, Associate Professor, Associate Professor of the Department of English language, literature with teaching methods of Mukachevo State University, Uzhhorodskaya St., 26, Mukachevo, 89600, tel.: (03131) 240-20, https://orcid.org/0000-0002-4951-0074

\title{
ACADEMIC INTEGRITY AS AN IMPORTANT COMPONENT OF QUALITY EDUCATION
}

\begin{abstract}
The article examines the importance of academic integrity in the educational process for training a competitive specialist who is able to independently conduct research, honestly and respect their achievements. It is noted that the moral and ethical norm serves as a qualitative guideline and standard for realizing one's own responsibility for violating ethical standards in education. The article notes that, first of all, academic integrity is a moral and ethical norm that all representatives of the educational and scientific environment must adhere to. Defining the essence of the concept, it begins with the behavior of students, parents, and the school administration. Academic virtue becomes particularly relevant precisely because such a moral and ethical norm serves as a qualitative reference point and standard, which is usually equated with. It is suggested to adhere to simple but fairly effective standards for maintaining honest educational relationships during Higher Education. It is recommended to familiarize yourself with the elements of studying academic integrity in European educational institutions. The opinion of promising experts on the development of emotional intelligence is noted. In the modern world, this comes to the fore: only the interaction of developed intelligence and an emotionally sensitive state will help students achieve efficiency in choosing their future profession. Such a symbiosis will form a comprehensive personal development, strengthen knowledge and skills, and promote a serious image. It is noted that each higher educational institution, each department is guided by the established percentages of uniqueness of the text. A number of universities have signed an agreement with Unicheck to check their work for plagiarism. The principle of operation of the platform is that the system uses modern technologies and intuitive design to improve the quality and originality of texts. It is noted that the problem of observing academic integrity cannot be solved in a year or two: it refers to moral and ethical standards. While it is necessary to emphasize respect for each other twice a week, it is necessary to devote more time to writing.
\end{abstract}

Keywords: academic integrity, morality, ethics, respect, trust, research, result.

Постановка проблеми.Формування системи моральних цінностей завжди $\epsilon$ і буде на першому плані у цивілізованому суспільстві.У сучасному світі, де 
існує усюдисущий Інтернет, надзвичайно важко утриматись від спокуси не «позичити» щось нове для написання роботи, реферату, статті. Так, це не злочин, якщо ти робиш правильні посилання на джерела, якщо не привласнюєш собі чужі думки, якщо не перекладаєш 3 іншої мови, не фальсифікуєш не фабрикуєш, не оприлюднюєш вже оприлюднені результати. Необхідно регулювати сферу освітнього простору та можливість закладів вищої освіти реалізовувати принцип здорової конкуренції в контексті Положення про академічну доброчесність.

Аналіз останніх досліджень і публікацій. Проблема сутності формування академічної доброчесності у вищій школі України є відносно новим предметом дослідження.Основні і найбільш поширені форми академічної нечесності у різних напрямах та рівнях освіти і наукипроаналізував А Мельничук (2016). Наявність зв'язку між політичною та академічною культурами в різних країнах обгрунтовано довела Л. Півнева (2005). Академічну чесність в контексті сталого розвитку університету, як національну потребу та соціальний капітал, як необхідну передумову ефективного управління сучасним університетом в умовах автономіі представили в колективній монографіï $\mathrm{T}$. Фініков, А. Артюхов, В. Турчиновський, Т. Добко та інші (Фініков, \& Артюхов. (Ред.), 2016) [1c. 199].

3 початку 2000 років поняття «академічна доброчесність» широко почало використовуватись у навчальному та науковому середовищі. Вперше про зазначене поняття було визначено у Законі України «Про освіту» у 2017 році [2].

Мета статті полягає урозкритті поняттяакадемічна доброчесність як важливої складової якісної освіти України.

Виклад основного матеріалу.Академічна доброчесність відноситься до широкого спектру життєвих реалій: від шкільного життя до значущих категорій в науковому середовищі. На превеликий жаль, існує думка, що академічна доброчесність стосується тільки вищої школи та науки.

У Законі України «Про освіту» визначається, що «Академічна доброчесність - це сукупність етичних принципів та визначених законом правил, якими мають керуватися учасники освітнього процесу під час навчання, викладання та провадження наукової (творчої) діяльності з метою забезпечення довіри до результатів навчання та/або наукових (творчих) досягнень» [3].

Насамперед - це морально-етична норма, яку повинні дотримуватись всі представники освітнього і наукового середовища. За визначенням суті поняття вона починається $з$ поведінки учнів, батьків, адміністрації школи. Особливість актуальності академічної доброчесності полягає саме тому, що така моральноетична норма служить якісним орієнтиром, еталоном, на який прийнято рівнятись. Чесність, довіра, справедливість, повага, відповідальність фундаментальні цінності академічної доброчесності: саме на такі вагомі складові наголошує Міжнародний центр академічної доброчесності [9]. 
Фундаментальні морально-етичні цінності необхідно виховувати, прищеплювати та вчити відстоювати ще зі шкільних років. Рівність можливостей, прозора діяльність, сумлінність, повага прав і свобод інших осіб, - всі ці орієнтири важливі в як процесі навчання, так i в наукових дослідженнях. Вони є складовою академічної доброчесності і слугує фактором справедливості та відповідальності у навчально-науковій сфері.

У століття глобалізації уникати тенденції комунікативного середовища неможливо. Використовуючи новітній контент освітньої галузі, якість наукової роботи залишається на першому місці. Перспективні фахівці запевняють, що емоційний інтелект виходить на перший план: лише взаємодія розвиненого інтелекту та емоційно-чутливого стану допоможе нам досягти результативності в майбутньому. Такий симбіоз допоможе формувати всебічний розвиток особистості, зміцнювати знання і навички та встановлювати сприятливий імідж для особистості, для закладу освіти, для освітньої системи. Вміння використовувати інтелект та керувати своїми емоціями $\epsilon$ надзвичайно важливим для дослідників і вчених.Розвинений інтелект допомагає у створенні системи особистої ефективності, тобто, володіти ним і вміти контролювати свій емоційний стан - це прямий шлях до успіху. Використовуючи наукові досягнення, людина збагачує свій інтелект, свою обізнаність, своє вміння аналізувати та систематизувати набуті знання. У зв’язку 3 впровадженням дистанційної форми навчання, 3 стрімким розвитком інформаційнокомунікативних технологій у окремих студентів виникає бажання отримати диплом про вищу освіту не прикладаючи до цього процесу певних зусиль [8].

Користуючись статтею 42 Закону України «Про освіту», необхідно дотримуватись добросовісності оформлення посилань у наукових працях та публікаціях, звертати увагу на юридичний аспект цього питання та враховувати достовірну інформацію і об'єктивність результатів [3].

Академічна доброчесність, як оцінювач критеріїв у науковому середовищі, виступає мірою захисту автора (авторів), методів дослідження та юридичного захисту їхньої інтелектуальної власності. Для учасників освітнього процесу, академічна доброчесність, у багатьох випадках, полягає у тому, щоб «не зловили на плагіаті». У порушенні доброчесності зауважується на несправедливі звіти, які надаються у ті або інші відділи та організації; на несправедливе оцінювання знань студентів; на фальсифікат проходження виробничих практик та на недостатню інформованість здобувачів щодо наслідків порушення правил академічної доброчесності.

Імітація роботи - один із серйозних ворогів академічної доброчесності i справедливої оцінки роботи. Така імітація надзвичайно ускладнює навчання $\mathrm{i}$ роботу чесним здобувачам освіти та науковцям. Здобувачі, у період навчання, отримують якісні, професійні знання і слідують морально-етичним нормам академічної доброчесності. Задача викладачів полягає у формуванні професійних компетентностей студентів, що допоможе їм стати 
конкурентноспроможними на сучасному ринку праці. Своєчасне та систематичне ознайомлення iз загальноприйнятимиморальних i етичних правилами академічної доброчесності, нададуть можливість здобувачам нести відповідальність за свої дії, за результати навчання, за зміст дипломних та магістерських досліджень.

Кожен заклад вищої освіти, кожна кафедра перевіряє індекс унікальності письмового дослідження студента. Для перевірки робіт на плагіат існує підписана угода ряду університетів 3 компанією Unicheck. Принцип роботи платформи полягає у використанні системою сучасних технологій та інтуїтивного дизайну для підвищення якості й оригінальності текстів [7].

Платформа turnitin пропонує «10 Types of Plagiarism», що становить собою перелік видів академічного плагіату (ранжованих за ступенем тяжкості й частотою появи в текстах), укладений наоснові результатів опитування близько 900 викладачів ВН3 світу: 1. Clone: копіювання, точне відтворення (слово в слово) чужого тексту й видавання його за свій. 2. CTRL-C: містить значну частину тексту одного джерела без змін. 3. Find - Replace: зберігається основний зміст джерела зі зміною ключових слів і фраз. 4. Remix: парафрази матеріалів кількох джерел упорядковуються так, щоб текст виглядав цілісним. 5. Recycle - це, по суті, дублювання автором власних результатів (т. зв. «самоплагіат»), значних шматків раніше опублікованих текстів без посилань. 6. Hybrid - це бездоганне поєднання цитованих джерел і скопійованих абзаців без посилання. 7. Mashup - мікс, змішування матеріалів, скопійованих із кількох джерел. 8. 404 Error - «Помилка 404»: текст містить посилання на неіснуючі джерела, недостовірні відомості про джерела. 9. RSS Feed: текст має належне оформлення цитат, але майже не містить оригінальних думок. 10. Re-tweet: текст містить належне цитування, але, по суті, дублює формулювання та/або структуру первісного (оригінального) тексту [1,4].

Ознайомлюючись 3 європейським принципом щодо академічної доброчесності, необхідно зауважити, що його за кордоном називають Кодексом честі. Це не означає, що у зарубіжних вузах відсутній плагіат у освітній системі. У ЄС було проведено масштабне дослідження, яке стосується плагіату у вищій освіті. Воно відоме як IPPHEAE (Impact of Policies for Plagiarism in Higher Education Across Europe), «Вплив політик щодо плагіату у вищій освіті в Свропі»). Результати цьогодослідження як щодо кожної країни, так і щодо Європи в цілому доступні за інтернет-адресою http://plagiarism.cz/ippheae/[6].

Боротись 3 плагіатом у студентських колах достатньо важко. Дослідження, які проводились у європейських освітніх закладах, свідчать, що в Європі відсутня єдина думка щодо плагіату. Студенти можуть у свій захист заявити, що вони не списували, не користувались чужим текстом, а просто його використали для відповіді на запитання. Викладач не може довести зворотне. Жодна установа у Свропі не володіє ідеальним способом протидії академічним 
зловживанням здобувачів. Отже, це хибна думка вважати, що у європейських вузах відсутній плагіат.

Цю проблему за рік-два неможливо вирішити: вона належить до моральноетичних норм і саме тому необхідно студентам частіше наголошувати на повазі один до одного, на необхідності більше часу у своєму розкладі відводити на виконання письмових робіт. Всім відомо, що існують шахрайські сайти, які пропонують написати за окрему винагороду письмову роботу, але потім вони можуть шантажувати здобувача освіти, маніпулювати ним, змушувати замовляти у них і інші види робіт, а у разі відмови, загрожувати їм розкриттям i повідомленням у заклад, де вони навчаються.

Студенти є частиною навчальної спільноти. Дії, які можуть підірвати особистісну i вузівську репутацію впливатимуть i на майбутнє молодого фахівця. Виявлення плагіату у роботах можуть статися вже після закінчення навчання, і установа, яка працевлаштувала випускника закладу вищої освіти, може його звільнити, а у випадку із закладом - $\epsilon$ ймовірність, що він не пройде акредитацію. Викладачі і стейкхолдери очікують від своїх випускників відповідальну, чесну, і зважену поведінку у освітній сфері.

Здобувачі освіти можуть відчувати себе пригніченим від роботи, яку необхідно виконати; постійно атакує відчуття нестачі часу; ускладнює процес навчання робота над декількома завданнями, які повинні бути виконані в один i той же термін; втрата інтересу до навчального матеріалу; нестача базових знань, - це одні з вагомих причин недобросовісного ставлення до навчання, що провокують використовувати чужі думки, публікації та напрацювання.

Необхідно впроваджувати у життя тайм-менеджмент, який дозволить спланувати управління часом: скорегує дедлайн виконання робіт, правила i принципи організаціїчасу i, тим самим, сприятиме досягненню максимальнокорисної ефективності у підготовці будь-якій справі.Стрес і перевантаження не мають впливати на результат дій. Тільки належні заходи нормативного, організаційного та правового характеру забезпечать належний рівень довіри до академічного і професійного середовища.

Чесність, довіра, повага, справедливість та відповідальність - основа академічної доброчесності. Масове порушення етичних правил, несанкціонована співпраця, шахрайство або сприяння академічній нечесності причини покарання згідно $з$ пунктом 5 статті 42 «Академічної доброчесності» закону України «Про освіту»[3].

У сучасному суспільстві виникає необхідність довіри цінностям свого розвиненого інтелекту та емоційно-чутливого стану.

Закон України «Про освіту» попереджає, що науково-педагогічні працівники, здобувачі освіти несуть відповідальність за незаконне використання інтелектуальної власності іншої особи. Необхідно проводити дослідження чесно,не копіювати ідеї, результати, чужі думки без посилання на джерело.Задача справжньої науки - продемонструйте свої власні досягнення. 
Викладач радить здобувачам освіти не копіюйте відповіді іншого студента; не звертатись 3 проханням виконати роботу за себе; не вигадуйте результати; не використовуйте електронні або інші пристрої під час іспитів; приймати виправлення від викладача як частину процесу навчання; демонструйте свої власні здібності та успіхи; не дозволяти іншому студенту копіювати відповіді на завданнях або іспитах.

Американські університети вже набули величезний досвід у створенні таких кодексів честі, де основою етичних норм для викладачів і студентів $є$ поняття «academic integrity» (академічна порядність), яке, в свою чергу, виховують нову молоду генерацію чесних науковців.

Дотримання академічної етики сприятиме розвитку науки у більш якісному руслі. Число проявів академічної недобросовісності значний i збільшується 3 кожним роком, при цьому списування і плагіат вже в середніх школах став носити масовий характер. Отже, заклади вищої освіти, заклади, де здобувачі отримують середню спеціальну освіту стають останнім шансом, де можна подолати кризу непорядності в освіті. Так, вже йдеться про кризу академічної доброчесності. Користування чужими думками, видаючи їх за свої, відбувається ще 3 шкільних років. Отже, виховувати академічну етику, привчати до моральності щодо написання власних робіт необхідно продовжувати і надалі ще у більш терплячий спосіб.

Викладачі, спілкуючись між собою на кафедрах, теж повинні піднімати питання доброчесності у роботі. 3 прийняттям Болонської хартії, європейські університети визначають цілі вищої освіти в умовах великих змін, обумовленихрозвитком масової освіти та новими соціально-епідеміологічними викликами.

Зазначаючи основні складові академічної доброчесності, необхідно виділити наслідки, які можуть бути під час прояву недобросовісності у навчанні. Перш за все, це нераціональне використання часувикладачів, у тому числі на боротьбу з плагіатом, що знижує престижність їхньої праці та якість навчання. Академічна недобросовісність тягнеза собою наукову недобросовісність, яка гальмує розвиток наукових досліджень і істотно знижує ix ефективність. Вона приводить до значного зниження рівня конкурентоспроможності як студентів так і викладачів.

Для покращення та полегшення роботи викладачів, доречно ввести курс 3 академічної доброчесності, на якому ознайомлювати здобувачів освіти 3 основними категоріями доброчесності у науці та наслідками і санкціями, які можливі під час порушення морально-етичних норм; про необхідність відсутності плагіату у роботах, про правильне оформлення посилань, цитат. Виникає потреба у поясненні того, що недопустимо порушувати авторські права і представляти їх за свої.

Звичайно, необхідно проаналізувати ті причини, які спонукають до плагіату. Необхідно звернути увагу на те, що багато сайтів на перевірку 
унікальності тексту є платними і непосильними для студенства. Не можна забувати і по недосконалу систему захисту авторських прав, інтелектуальної власності та, іноді, низькі моральні якості окремих авторів. Часто самі науковці використовують метод самоплагіату.

Висновки. Отже, дотримання академічної доброчесності $\epsilon$ важливим складником розвитку науки, виховання молодої генерації у чесному, справедливому, відповідальному напрямку роботи. Довіра та повага - моральні принципи, які керують академічною доброчесністю. Необхідно запобігати причини можливості допуску плагіату у академічному середовищі. Підтримкою академічної доброчесності слугує створення умов до запобігання використання недоброчесності у науковому середовищі. Необхідно вживати інституційні заходи щодо більш детального вивчення причин недотримання Положення про академічну доброчесність та створювати необхідні умови для їх подолання.

\section{Jimepamypa:}

1. Types of Plagiarism. URL: http://go.turnitin.com/posters/plagiarism-spectrum.

2. Про вищу освіту: Закон України №1556-VII. Відомості Верховної Ради Украӥни. 2014. URL: https://zakon.rada.gov.ua/laws/show/1556-18\#Tex.

3. Про освіту: Закон України. URL: https://zakon.rada.gov.ua.

4. Колесніков А. Академічна доброчесність в українському освітньо-науковому просторі: проблеми та соціальні загрози. URL: http://rarrpsu.wunu.edu.ua〉rarrpsu>article vview2020.

5. Маслова Н.Г. Академічна свобода та академічна відповідальність. Науковий вісник Ужсгородського національного університету. Серія «Право». 2017. Вип. 43, Том 1. С. 72-76.

6. Ніколаєв Є. Як просувати цінності академічної доброчесності... URL: https://www.skeptic.in.ua〉promoting-integrity.

7. Сервіс перевірки на плагіат Unicheck. URL: https://unicheck.com.

8. Тодорова I.C. Компоненти академічної доброчесності студентів та умови іiі формування. Витоки педагогічної майстерності: наук. журн. Полтава, 2019. Вип. 24. С. 199.

9. Фундаментальні цінності академічної доброчесності. URL: https//www.donnu.edu.ua > sites > 2019/08 > Fun...

\section{References}

1. Types of Plagiarism. Retrieved from http://go.turnitin.com/posters/plagiarism-spectrum. [in English].

2. Pro vyshchu osvitu: Zakon Ukrainy №1556-VII [On higher education: Law of Ukraine №1556-VII]. (2014). Vidomosti Verkhovnoi Rady Ukrainy - Bulletin of Verkhovna Rada of Ukraine. Retrieved from https://zakon.rada.gov.ua/laws/show/1556-18\#Tex. [in Ukrainian].

3. Pro osvitu: Zakon Ukrainy [On education: Law of Ukraine]. Retrieved from https://zakon.rada.gov.ua. [in Ukrainian].

4. Kolesnikov, A. Akademichna dobrochesnist v ukrainskomu osvitno-naukovomu prostori: problemy ta sotsialni zahrozy [Academic integrity in the Ukrainian educational and scientific space: problems and social threats]. Retrieved from http://rarrpsu.wunu.edu.ua>rarrpsu $>$ article $v i e w 2020$. [in Ukrainian].

5. Maslova, N.H. (2017). Akademichna svoboda ta akademichna vidpovidalnist [Academic freedom and academic responsibility]. Naukovyi visnyk Uzhhorodskoho natsionalnoho universytetu. Seriia «Pravo»- Scientific Bulletin of Uzhhorod National University. Law Series, 43, 1, 72-76. [in Ukrainian]. 
6. Nikolaiev, Ye. Yak prosuvaty tsinnosti akademichnoi dobrochesnosti... [How to promote the values of academic integrity...]. Retrieved from https://www.skeptic.in.ua>promoting-integrity. [in Ukrainian].

7. Servis perevirky na plahiat Unicheck [Unicheck plagiarism check service]. Retrieved from https://unicheck.com. [in Ukrainian].

8. Todorova, I.S. (2019). Komponenty akademichnoi dobrochesnosti studentiv ta umovy yii formuvannia [Components of students' academic integrity and conditions of its formation]. Vytoky pedahohichnoi maisternosti - The origins of pedagogical skills, 24, 199. [in Ukrainian].

9. Fundamentalni tsinnosti akademichnoi dobrochesnosti [Fundamental values of academic integrity]. Retrieved from https//www.donnu.edu.ua > sites > 2019/08 > Fun... [in Ukrainian]. 